УДК 629.4.077-592

Канд. техн. наук В.В.Бондаренко, асист. Я.В. Дерев'янчук

Cand. of techn. sciences V.V. Bondarenko, assistant Ya.V. Derevianchuk

\title{
УДОСКОНАЛЕННЯ СИСТЕМИ КОНТРОЛЮ \\ ЕЛЕКТРОПНЕВМАТИЧНИХ ГАЛЬМ ПОЇЗДІВ
}

\section{IMPROVEMENT OF CONTROL ELECTRO-BRAKE TRAINS}

\author{
Представив д-р техн. наук, професор І.Е. Мартинов
}

Вступ. Електропневматичні гальма сучасного пасажирського рухомого складу відіграють важливу роль у забезпеченні безпеки руху. Вони мають відмінну керованість, синхронність ступенів гальмування і відпуску, дозволяють точно регулювати швидкість руху i зупинку поїзда.

Аналіз останніх досліджень i публікацій. У проаналізованій літературі [1-3] відмічено ряд недоліків існуючих електропневматичних гальм, зокрема відсутність обмеження тиску в гальмовому циліндрі при гальмуванні положенням VA крана машиніста та неавтоматичність дії. Одними 3 основних недоліків $\epsilon$ незадовільне забезпечення контролю та недостатня надійність їх роботи, що значною мірою залежить від надійності електричного кола, особливо міжвагонних з'єднань та інше. Зі збільшенням кількості одиниць рухомого складу в поїзді на передній план виходить проблема відсутності надійного управління та контролю роботи електропневматичних гальм.

На залізницях Росії та України застосовують декілька простих систем. Контроль електричного кола при найбільш розповсюдженій схемі електропневматичних гальм (рис. 1) здійснюється за рахунок контрольного проводу №2 і подачі через нього, кінцевого замикача (КЗ) i робочого проводу №1 змінної напруги. Про справність електричного кола сигналізує сигнальна лампа, ввімкнена послідовно. Для підвищення надійності роботи електропневматичних гальм використовують дублювання живлення електроповітророзподільників (ЕПР) по контрольному проводу №2 шляхом замикання перемикача (ДП), але при цьому втрачається контроль електричного кола. 


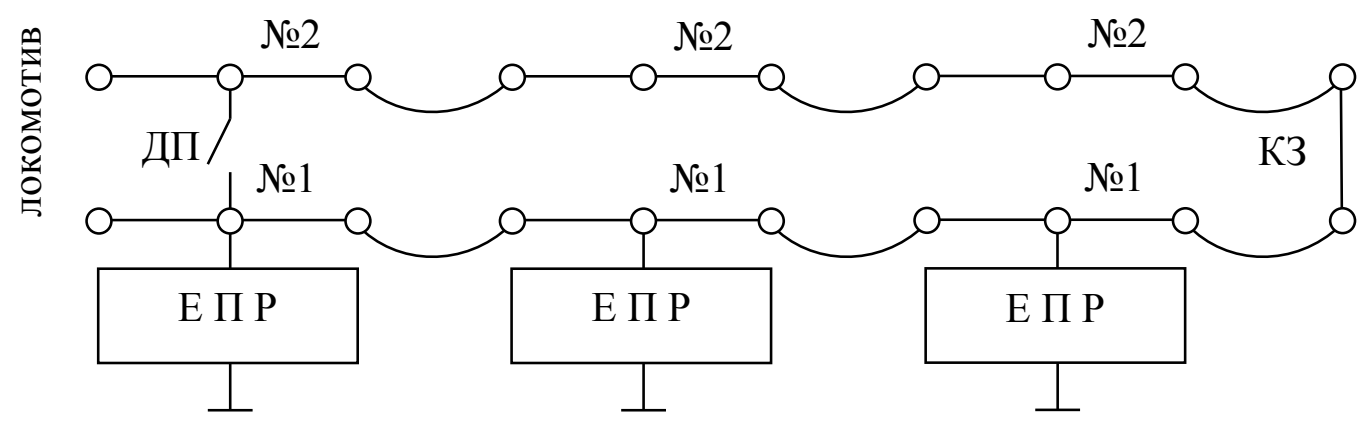

Рис. 1. Найбільш розповсюджена схема контролю електропневматичних гальм

\section{Удосконалити} електропневматичних можливо шляхом введення вагоні датчиків тиску (ДТ) гальмового циліндра (рис. 2), що дає змогу при гальмуванні з'єднувати робочий №1 i контрольний №2 проводи, підвищуючи надійність електричного з'єднання навіть одночасно в декількох місцях. До з'єднувального рукава хвостового вагона під'єднують кінцеву заглушку 3 напівпровідниковим діодом, що дозволяє при відпущених гальмах, при подачі позитивного імпульсу напруги на робочому проводі №1 відносно контрольного №2 контролювати невідпущені гальма. Датчик тиску (ДТ) на загальмованому вагоні замикає робочий №1 i контрольний №2 проводи. При повністю відпущених гальмах струм не проходить. При подачі негативного імпульсу напруги на робочому проводі №1 відносно контрольного №2 контролюють електричне коло, що проходить через ці проводи, i діод у кінцевому замикачі (КЗ).

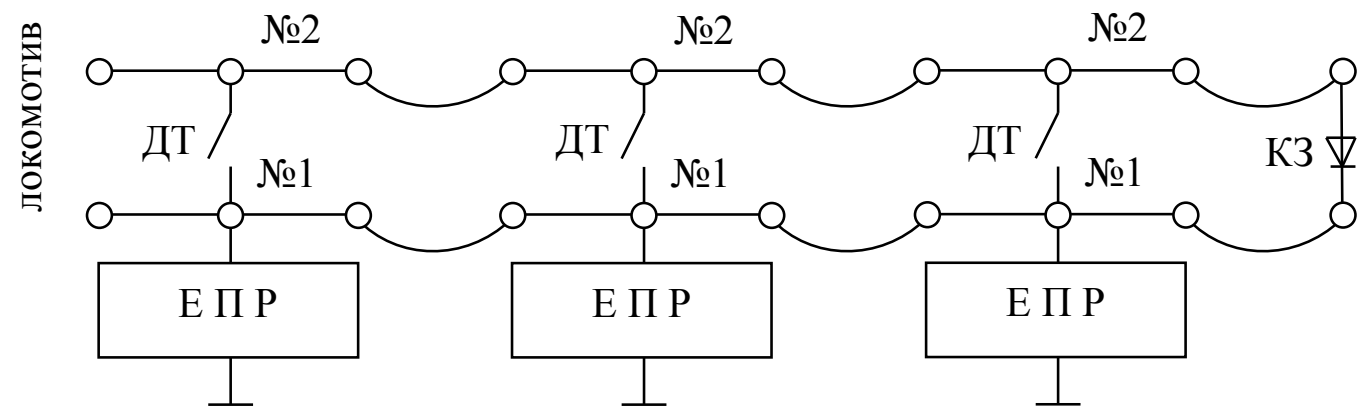

Рис. 2. Система контролю гальм, що розроблена російськими винахідниками

Мета статті. Розроблення нової сучасної системи дистанційного контролю електропневматичних гальм поїздів, яка призначена для виявлення несправностей та попередження можливих відмов гальмової системи під час рейсу та при технічному обслуговуванні i ремонті поїздів.
Виклад основного матеріалу. На кафедрі вагонів УкрДАЗТ під керівництвом доктора технічних наук I.Е. Мартинова розроблена нова система дистанційного контролю електропневма-тичних гальм поїздів, яка дозволяє під час рейсу поїзда та на зупинці (при технічному обслуговуванні і ремонті) здійснювати контроль технічного 
стану гальм, випробування та ідентифікацію несправностей [4]. Діючий прототип системи контролю гальм поїздів (рис. 3) перевірено на базі гальмової випробувальної лабораторії, яка дозволяє імітувати роботу гальм пасажирських та вантажних вагонів.

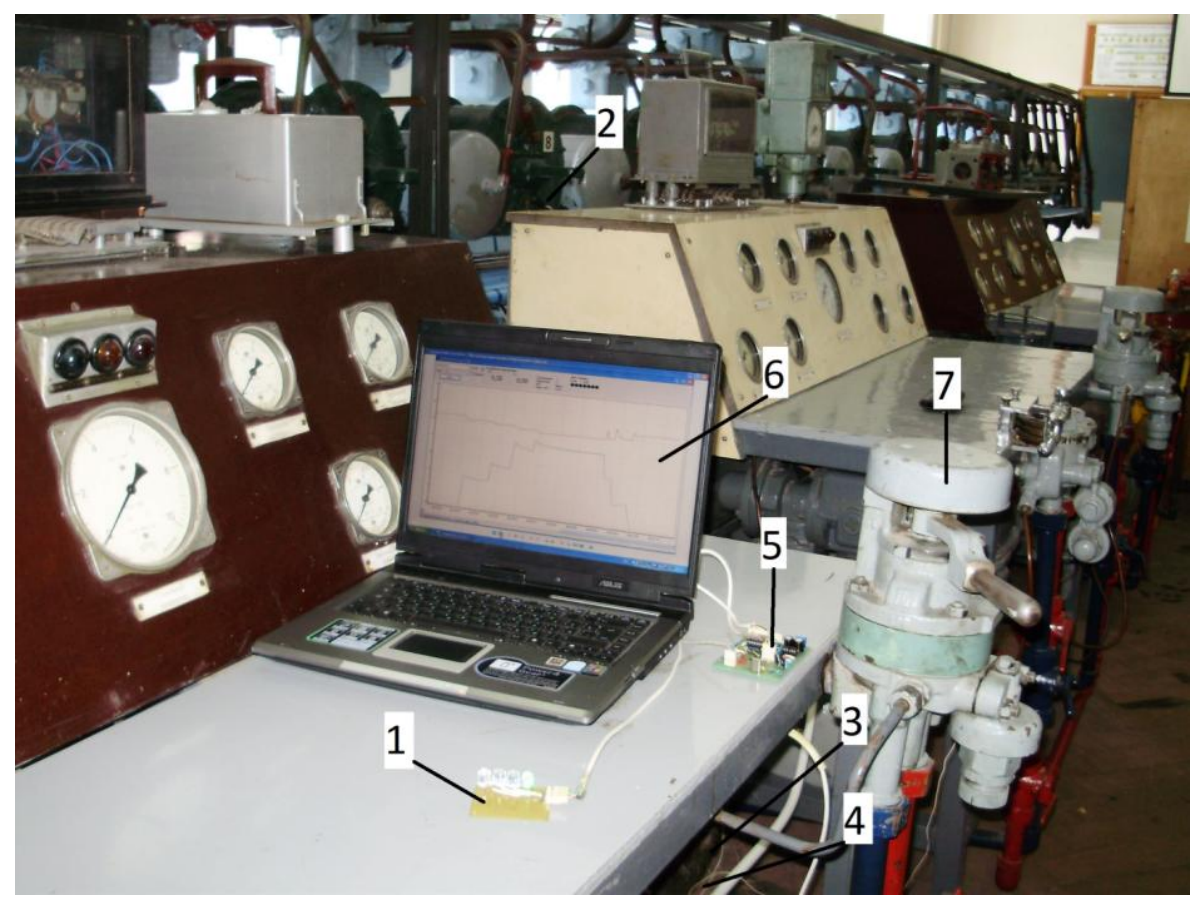

Рис. 3. Прототип системи дистанційного контролю гальм поїздів на базі випробувальної станції кафедри вагонів:

1 - світлова індикація вагона, 2 - датчик Д1 гальмового циліндра, 3 - датчик Д2 гальмової магістралі, 4 - датчик Д3 електропневматичного гальма, 5 - блок АЦП, 6 - ПК штабного вагона або АРМ ПТО, 7 - кран машиніста

Датчики Д1-Д3 реєструють такі параметри гальмової системи вагона: Д1 тиск в гальмовому циліндрі, Д2 - тиск в гальмовій магістралі і Д3 - напругу на електроповітророзподільнику для контролю електропневматичних гальм.

Отримані від датчиків Д1-Д3 сигнали оцифровують та порівнюють 3 їх еталонними значеннями за допомогою електричної схеми (рис. 4) на основі мікроконтролера Atmega, який встановлено на вагоні. Поява відхилення свідчить про одну 3 діагностичних ознак. Рід несправності виявляється за величиною відхилення.

Вимірювання величини і полярності напруги на робочому проводі електроповітророзподільника відносно корпусу здійснюється через обмежуючий резистор R11. Діоди VD3 i VD4 пропускають струм залежно від полярності: +50 В через верхній за схемою, -50 В через нижній, при змінній напрузі діоди відкриваються по черзі. Конденсатори С6C9 згладжують стрибки напруги та усувають високочастотні завади. Оптопари 4N25 забезпечують повну гальванічну розв'язку електричного кола управління електропневматичними гальмами й електричного кола пристрою. Напруга 3 оптопар подається на аналого-цифровий перетворювач мікроконтролера Atmega, де обробляється за заданою програмою. До роз'єму XS5 підключають аналогові датчики для вимірювання тиску Д1, Д2 та 
інші датчики 3 аналоговим вихідним сигналом. На виводах роз'єму XS3 вимірюють дискретний сигнал. Про роботу гальма в основних режимах сигналізують відповідні світлодіоди, що під’єднують до роз'єму ХР2.

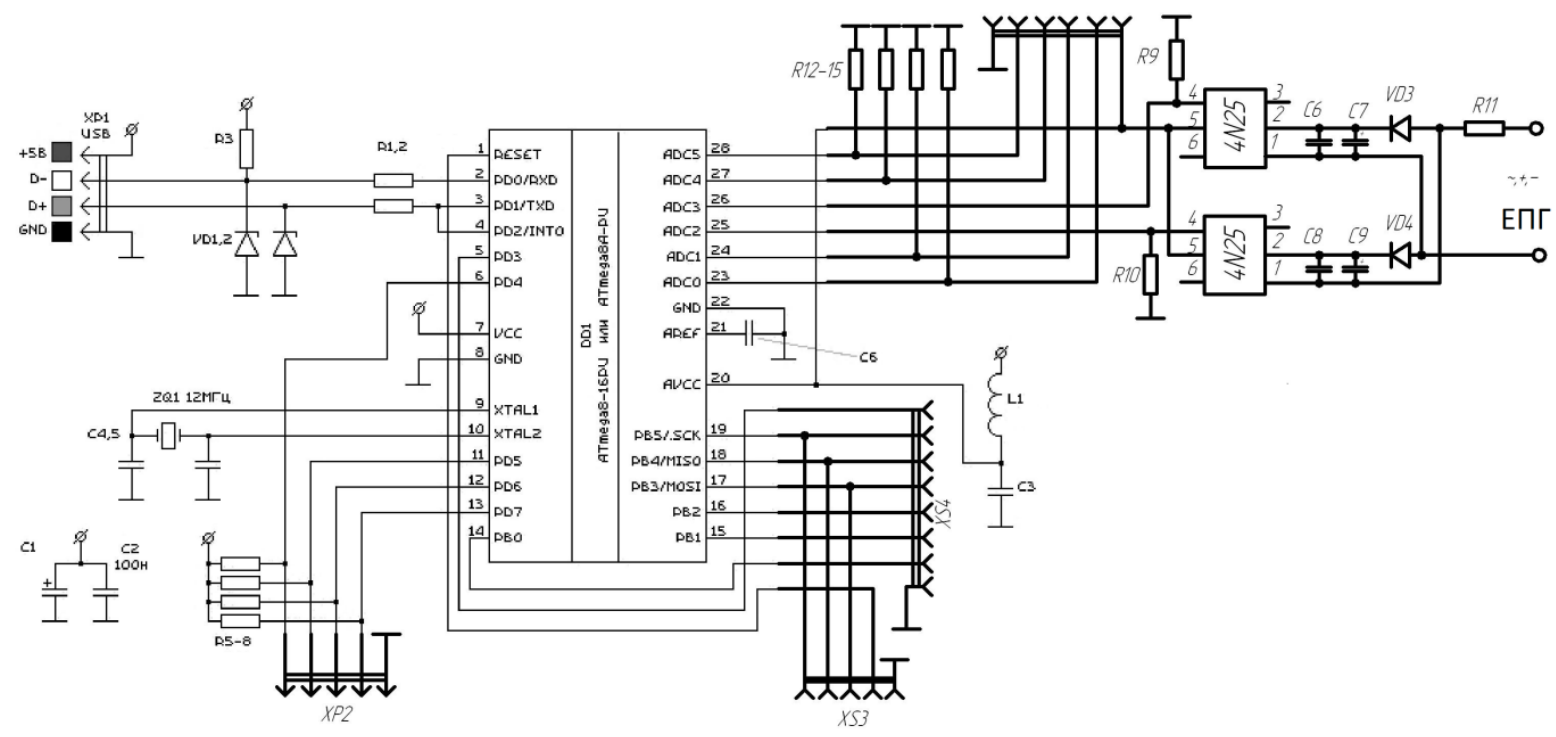

Рис. 4. Схема контролю напруги електропневматичних гальм

Для візуалізації основних режимів роботи гальмового обладнання та розширення функцій системи було додатково розроблено систему індикації стану гальм (рис. 5) 3 виводом інформації на кузовні світлодіоди (встановлено по 4 діоди різного кольору з кожного боку вагона). Показання світлодіодів слід читати так:

„зелений” - електропневматичні гальма працюють, гальмо відпущене;

„жовтий” - тиск у гальмовому циліндрі (ГЦ) відповідає першому ступеню гальмування;

„червоний” - тиск у ГЦ відповідає другому i наступним ступеням гальмування, повному службовому гальмуванню та екстреному гальмуванню; допустимий.

„білий” - тиск у ГЦ перевищує

Дана система індикації забезпечує зручність при випробуванні та контролі роботи гальм за рахунок світлової індикації виміряного рівня і стану.

Запропонована схема може працювати автономно, від бортового джерела електричної енергії. При підключенні по USB-кабелю можна здійснювати бездротову передачу даних на електронно-обчислювальний комплекс вагона для зберігання, обробки і передачі в інформаційно-діагностичну мережу поїзда згідно 3 [5] або провідну мережу. Встановлення на локомотиві та вагонах допоміжних модулів дозволяє здійснювати не тільки контроль, а й управління електропневматичними гальмами. Електропневматичні гальма можуть також бути доповнені пристроями для регулювання гальмівної сили в залежності від швидкості руху, що значно зменшує гальмівний шлях при високих швидкостях руху i використанні чавунних колодок. Застосування модулів управління i контролю електропневматичними гальмами дозволяє реалізовувати інтелектуальні протиюзові системи, що значно зменшують гальмівний шлях, запобігають пошкодженню колісних пар незалежно від стану колії. 


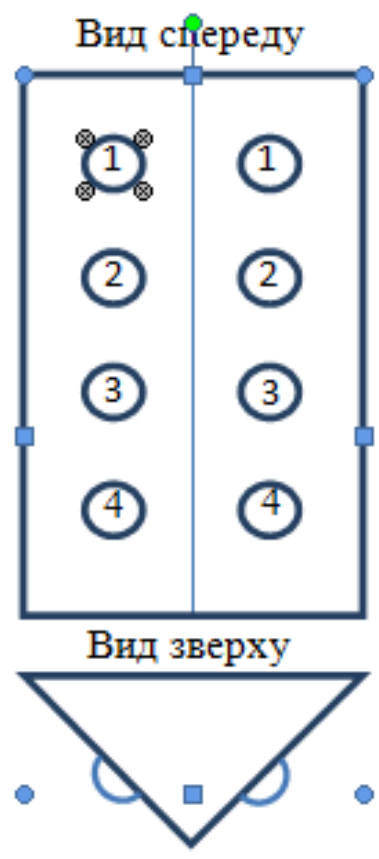

Рис. 5. Світлова індикація режимів роботи гальм:

1 - зелений колір; 2 - жовтий колір; 3 - червоний колір; 4 - білий колір

Висновки. Розроблена система дистанційного контролю дозволяє:

- контролювати величину та полярність напруги на робочому проводі електроповітророзподільника кожного вагона;

- контролювати величину напруги 3 аналогових датчиків інших систем; датчиків;

- контролювати стан дискретних

- здійснювати світлову сигналізацію роботи електропневматичних гальм;

- здійснювати сигналізацію роботи інших систем в залежності від стану датчиків;
- зберігати звіт про технічний стан об'єкта, для подальшого запису на бортовий електронно-обчислювальний комплекс;

- передавати дані на електроннообчислювальний комплекс для зберігання, подальшої обробки і передачі на сервер по стандартному USB кабелю;

- контролювати кількість спрацювань електропневматичних гальм вагона або інших систем, що дозволить ремонтувати їх по реальному ресурсу та збільшити міжремонтні терміни;

- здійснювати керування зовнішніми модулями ЕПГ.

\section{Список літератури}

1. Иноземцев, В.Г. Автоматическиетормоза [Текст]: учебник / В.Г. Иноземцев, В.М. Казаринов, В.Ф. Ясенцев. - М.: Транспорт, 1981. - 464 с.

2. Афонин, Г.С. Устройство и эксплуатация тормозного оборудования подвижного состава [Текст]: учебник для нач. проф. образования/ Г.С. Афонин, В.Н. Бращенков, Н.В. Кондратьев. - М.: Издательский центр «Академия», 2005. - 304 с. 
3. Удальцов, А.Б. Укрощение тормозной волны [Текст] /А.Б. Удальцов, С.Е. Либин // Локомотив. - 2006. - №3. - С.40-43.

4. Спосіб дистанційного контролю автоматичних гальм рейкового рухомого складу [Текст]: пат. України на корисну модель 55429 МПК (2009) В 61 К 9/00 G 015 5/14 / В.В. Бондаренко, Я.В. Дерев'янчук; власник Українська державна академія залізничного транспорту. - № u 201007799; заявл. 21.06.2010; опубл. 10.12.2010, Бюл. №23. - 4 с.

5. Спосіб забезпечення доступу до Інтернету у поїздах [Текст]: пат. 68074 України МПК (2012.01) G09F 19 / О.В. Устенко, В.В. Бондаренко, Д.I. Скуріхін; заявник та патентовласник Українська державна академія залізничного транспорту. - № u201111167; заявл. 20.09.2011; опубл. 12.03.2012, Бюл № 5.

Ключові слова: дистанційний контроль, гальма поїздів.

\section{Анотації}

Авторами розроблена нова система дистанційного контролю електропневматичних гальм поїздів, яка дозволяє під час руху поїзда та на зупинці, при технічному обслуговуванні і ремонті, здійснювати контроль технічного стану гальм, випробування та ідентифікацію несправностей. Оброблена інформація з датчиків гальмової системи вагона передається до бортового терміналу штабного вагона та/або наземного терміналу по каналах дротового зв’язку або GSM/GPRS та Wi-Fi.

Авторами разработана новая система дистанционного контроля электропневматических тормозов поездов, которая позволяет во время движения поезда и на остановке, при техническом обслуживании и ремонте, осуществлять контроль технического состояния тормозов, опробование и идентификацию неисправностей. Обработанная информация с датчиков тормозной системы вагона передается на бортовой терминал штабного вагона и / или наземного терминала по каналам проводной связи или GSM / GPRS и Wi-Fi.

The authors developed a new system of trains electropneumatic brake remote control, which allows control of their technical condition, checking and identifying faults during race and stop. Processed information is transferring from sensors of brakes to the onboard terminal and /or ground terminal using wire connection or GSM / GPRS and Wi-Fi. 